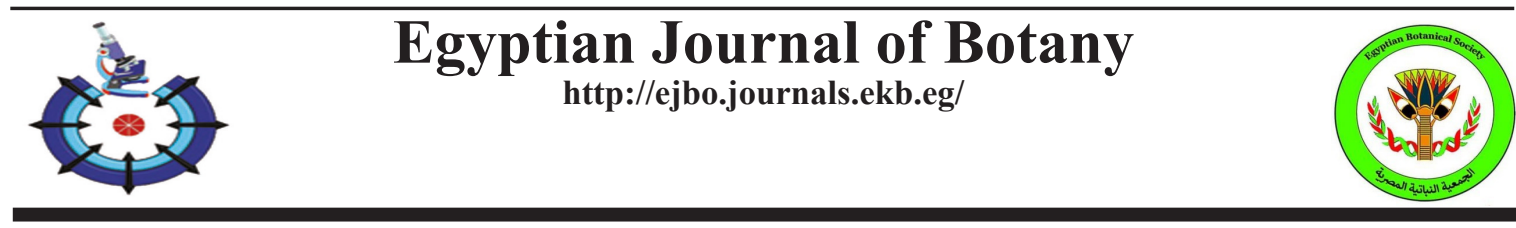

\title{
Seed Germination, Seedling Growth and Photosynthetic Responses \\ to Temperature in the Tropical Tree Moringa oleifera and Its Relative Desert, Moringa peregrina
}

\author{
Abdulkhaliq A. AL-Shoaibi \\ Biology Department, Faculty of Science, Taibah University, P.O. Box 30002 Almadinah \\ Almunawwarah, Saudi Arabia.
}

\begin{abstract}
TORINGA oleifera and Moringa peregrine are cultivated in many areas in Almadinah Almunawwarah, western part of Saudi Arabia. The aim of the present study is to examine the responses of seed germination, seedling growth and photosynthetic performance for two Moringa species to different temperature treatments; $15 / 12^{\circ} \mathrm{C}, 25 / 22^{\circ} \mathrm{C}$ and $35 / 32^{\circ} \mathrm{C}$; day/night. The obtained results indicated that seeds of both species could germinate at a wide range of temperatures with optimum temperature for highest percentage of germination, at $25^{\circ} \mathrm{C}$. The results showed that most parameters of growth and the photosynthetic performances of the two species were highest at $25^{\circ} \mathrm{C}$. However, the chlorophyll contents of M. oleifera and most values of chlorophyll fluorescence for both species were similar across the three temperature treatments. Additionally, the outcomes of this study showed that Moringa can be cultivated in many different regions with different temperatures.
\end{abstract}

Keywords: Moringa oleifera, Moringa peregrina, Photosynthetic responses, Seed germination, Seedling growth, Temperature.

\section{Introduction}

The Moringa genus contains 13 tree species and belongs to the Moringaceae family, most of them are found in the tropics (Olson \& Carlquist, 2001). Moringa oleifera is the most important species and the most widely distributed in Asia, Africa, and America due to its economic importance (Ramachandran et al., 1980; Leone et al., 2015); it believed to be native to subHimalayan north-eastern India (Pandey et al., 2011). The second most important species is Moringa peregrina, which is distributed in the arid regions of the Arabian Peninsula (El-Lamey, 2015). M. oleifera is a medium-sized tree reached 3-15m high (Boulos, 1999); it is a fast-growing tree and is believed to be tolerant to drought and heat (Hegazy et al., 2008). M. oleifera is used for multiple purposes, including food, feed, fuel and cosmetics, which has resulted in its widespread use, especially in the recent decades (Leone et al., 2015; Boukandoul et al., 2018). In Africa and Asia, Moringa is used as human food and in medicines because of the high content of minerals and vitamins in the different parts of the tree (Abd El-Hack et al., 2018; Khor et al., 2018). For example, it was reported that $M$. oleifera leaves contain considerable amounts of proteins, minerals, and amino acids, which make the plant a valuable fodder crop (Amaglo et al., 2010; Leone et al., 2015). The oil content in $M$. oleifera seeds, reaches approximately $35-45 \%$, with a high content of unsaturated fatty acids and $73 \%$ oleic acid (Ayerza, 2019). The high content of oleic oil in Moringa oil makes it a good source for high-quality biodiesel production (Da Silva et al., 2010; Boukandoul et al., 2018). Moringa seeds are a valuable source of oil, which is

Corresponding author email: Ashoaibi@taibahu.edu.sa

Received 16/2/ 2021; Accepted 24/3/ 2021

DOI: $10.21608 /$ ejbo.2021.63271.1631

Edited by: Prof. Dr.: Fawzy M. Salama, Faculty of Science, Assuit University, Assuit, Egypt.

(C2021 National Information and Documentation Center (NIDOC) 
promoted as a natural cosmetic emollient; it is pure, colourless, and tasteless and it is also used for medicinal purposes (Anjula et al., 2011; Abd El-Hack et al., 2018). Due to the multiple uses of the raw material from Moringa trees, their cultivation has spread worldwide to more than 80 countries (Pandey et al., 2011).

It has been reported that Moringa trees are well adapted to harsh environmental conditions, can grow in high temperatures and can highly considered drought and heat tolerant plant(Hegazy et al., 2008; El-Lamey, 2015; Wasonowati et al., 2019). The adaptation of plants to environmental stresses is usually associated with metabolic changes that resulted in the accumulation of a range of metabolites, such as sugars, phenols, and proline (Tesfay et al., 2011), that have a considerable impact on seed germination, seedling development and the productivity of plants (Tesfay et al., 2016). Tesfay et al. (2016) reported that temperature had a significant effect on the germination rate of $M$. oleifera seeds and radicle emergence was accelerated at $30 / 20^{\circ} \mathrm{C}$, leading to germination within $48 \mathrm{hrs}$. In general, plants developed adaptive strategies in response to biotic and abiotic stress, such as drought, salinity, and temperature. Although plant species differ considerably in the optimum temperature range for seed germination and growth performance, it has been reported that the optimal temperature for seed germination of $M$. oleifera is $30 / 20^{\circ} \mathrm{C}$ (Muhl, 2009; Muhl et al., 2011A). The growth and seed production of Moringa species might be affected by climatic conditions, particularly high temperatures, drought, and high levels of irradiance (Melesse et al., 2012; Hassanein \& Al-Soqeer, 2017; Wasonowati et al., 2019). In a recent study on the performance of several $M$. oleifera cultivars, variations in vegetative and reproductive growth traits were observed under dry, hot climate conditions (Zheng et al., 2019).

Photosynthesis is considered one of the most sensitive physiological processes in plants. It has been found that temperature is among the uncontrollable climate variables that have the greatest effect on regulating the process of photosynthesis (Urban et al., 2017). Elevated temperatures can reduce the photochemistry of PSII $\left(F_{v} / F_{m}\right)$, the assimilation of $\mathrm{CO}_{2}$ and the evolution of $\mathrm{O}_{2}$, resulting in a decrease in the light reactions of photosynthesis and the light saturation point of photosynthesis $\left(A_{\text {sat }}\right)$
(Savitch et al., 2000; Youssef, 2007). Elevated temperatures limit photosynthetic activity by affecting the transportation of electrons in the thylakoid membrane, carboxylation ability and Rubisco kinetics (Posch et al., 2019). It has also been found that the ratio of the linear quantum yield to the mean variable of fluorescence $\left(F_{v} /\right.$ $F_{m}$ ) decreases at elevated temperatures (Maxwell \& Johnson, 2000). Furthermore, the chlorophyll content was found to decrease when plants were exposed to elevated temperatures. Elevated temperatures inhibit chlorophyll biosynthesis and speed up its degradation (Ashraf \& Harris, 2013).

In the Almadinah Almunawwarah region, in the western part of Saudi Arabia, Moringa peregrina and Moringa oleifera are cultivated in different areas with different temperature conditions. Temperature is one of the main factors that determine the distribution of plants in these areas. The mean temperatures of the Almadinah Almunawwarah region range between $15^{\circ} \mathrm{C}$ and $35^{\circ} \mathrm{C}$ annually (Presidency of Meteorology and Environment, Saudi Arabia). Since there is a shortage of information concerning the responses of Moringa species to temperature change in this region, this study is performed to investigate the responses of seed germination, seedling growth and photosynthesis performance of these two Moringa species to three temperature regimes: $15 / 12^{\circ} \mathrm{C}$, $25 / 22^{\circ} \mathrm{C}$ and $35 / 32^{\circ} \mathrm{C}$; day/night.

\section{Materials and Methods}

\section{Seed germination}

The seeds of two Moringa species, M. oleifera and $M$. peregrina, were used to investigate the effects of temperature on germination. The seeds of $M$. oleifera were obtained from Al-Hilali Agricultural Company, while the seeds of $M$. peregrina were donated by the Jeeda Charity Community in the Al-Ula district, where the seeds are collected from their natural habitats. The experiments in this study were carried out in the Department of Biology, Faculty of Science, Taibah University, Almadinah Almunawarh, Saudi Arabia. For the germination test, seeds were sterilised by soaking in $0.1 \%$ mercuric chloride, washed in distilled water five times. The seeds were placed on two layers of Whatman No. 1 filter paper inside a Petri dish $(9 \mathrm{~cm} \times 1.6 \mathrm{~cm})$ and watered with $10 \mathrm{~mL}$ of distilled water. Each Petri dish contained 10 seeds, and four replicate Petri dishes were used for both Moringa species ( $M$. 
oleifera and $M$. peregrina). Three temperature treatments were used to test the temperature at germination $\left(15^{\circ} \mathrm{C}, 25^{\circ} \mathrm{C}\right.$ and $\left.35^{\circ} \mathrm{C}\right)$, and the Petri dishes were placed inside incubators in darkness. The emergence of the radicle from the seeds was considered as an indicator of germination. The germination process was recorded every day for the whole incubation period during two weeks.

\section{Plant growth parameters}

Seeds of the two Moringa species, M. oleifera and $M$. peregrina, were grown in plastic pots $(12 \mathrm{~cm} \times 20 \mathrm{~cm})$ containing $2 \mathrm{~kg}$ of compost. The pots were placed inside an environmentally controlled chamber (JSR 314-240, JS Research Inc., Gumsang-Dong 40-1, city of Gongju, Korea) with a photoperiod of $14 / 10 \mathrm{hrs}$. (light/ dark) and $60 \%$ relative humidity. Fluorescent and halogen lamps were used for illumination, resulting in $400 \mu \mathrm{moL} \mathrm{m} \mathrm{m}^{-2} \mathrm{~s}^{-1}$. For each Moringa species, four replicates were used for the three temperature treatments $\left(15 / 12^{\circ} \mathrm{C}, 25 / 22^{\circ} \mathrm{C}\right.$ and $35 / 32^{\circ} \mathrm{C}$; day/night). In each pot, five seeds were planted, and after emergence, the seedlings were thinned, leaving two per pot. The plants were irrigated with full-strength Hoagland solution to full field capacity. At the end of the experiment, 40 days after planting, the following growth parameters were measured: height of the plant, number of leaves, and fresh weight of the roots and shoots. To determine the dry weight, root and shoot samples were oven-dried for $48 \mathrm{hrs}$. at $80^{\circ} \mathrm{C}$. Leaf area was measured according to the method described by Pandey \& Singh (2011), using the weight of graph paper covered by the leaves. Then, the weight was converted to area using the following equation: leaf area $\left(\mathrm{cm}^{2}\right)=x / y$, where $x$ is the weight of the graph paper covered by the leaf and $y$ is the weight (gm).

\section{Photosynthesis measurements}

The rates of photosynthesis were measured using a 6400XT LICOR infrared gas analyser (LI-6400, LI-COR Inc., Lincoln, Nebrasks, United States of America) on the youngest fully expanded leaves, following methods described by Al-Shoaibi (2008). For photosynthesis and dark respiration, the fourth fully expanded young leaves were used. The leaf temperature was maintained at $25^{\circ} \mathrm{C}$ during the measurement process by using a Peltier cooling system. The leaves were illuminated steadily, with photon flux densities from 0 to $1500 \mu \mathrm{moL} \mathrm{m}^{-2} \mathrm{~s}^{-1}$. The net photosynthesis per leaf area and intercellular $\mathrm{CO}_{2}$ concentration $\left(c_{\mathrm{i}}\right)$ were determined by applying the equations of Von Caemmerer \& Farquhar (1981). $A_{\text {sat }}$ was determined at a saturating photosynthetic photon flux density of $1500 \mu \mathrm{mol}$ $\mathrm{m}^{-2} \mathrm{~s}^{-1}$ and at an ambient $\mathrm{CO}_{2}$ concentration of $410 \mu \mathrm{mol} \mathrm{mol}{ }^{-1}$.

The response of $A$ to the intercellular $\mathrm{CO}_{2}$ concentration $(\mathrm{ci})$ was estimated using the same gas exchange system over a range of $c a=50$ $550 \mu \mathrm{mol} \mathrm{mol}^{-1}$, with a photosynthetic photon flux density of $1500 \mu \mathrm{mol} \mathrm{m}^{-2} \mathrm{~s}^{-1}$ at a leaf temperature of $25^{\circ} \mathrm{C}$. The measurement of $A$ was first performed at a $\mathrm{CO}_{2}$ concentration equal to the ambient concentration in the environment where the plants were grown. To determine the initial slope of the $\mathrm{A} / \mathrm{ci}$ response, $\mathrm{ca}$ was gradually decreased over six steps to $50 \mu \mathrm{mol} \mathrm{mol}{ }^{-1}$. To check the original rate that might be regained, $c a$ was then restored to the ambient concentration. To complete the curve, the $c a$ was finally increased stepwise to $550 \mu \mathrm{mol} \mathrm{mol}{ }^{-1}$. The assumed amount of active phosphoenol pyruvate carboxylase in vivo, which is called 'carboxylation efficiency', was calculated from the gradient of the initial slope of the response of $A$ to $c i$, following the model of Collatz et al. (1992).

\section{Chlorophyll content determination}

The chlorophyll contents, which are expressed as the chlorophyll index, were determined by using a handheld chlorophyll content metre (Opti-Sciences Inc., CCM-200, United States). The chlorophyll contents were measured in the fourth expanded leaves, with four readings for each Moringa species and each temperature treatment. The average of the four measurements was used as the final chlorophyll content index.

\section{Chlorophyll fluorescence measurements}

The fluorescence of chlorophyll was measured by using a handheld fluorimeter (PEA, Hansatech, King's Lynn, Norfolk, U.K.). The measurements were performed on the youngest fully expanded leaves of the two Moringa species. Prior to the chlorophyll measurement, the leaves were darkadapted for 20min. For both Moring a species, the variable ratio of maximum fluorescence $(F v / F m)$ was measured four times for each temperature treatment, as described by Al-Shoaibi (2008).

\section{Statistical analysis}

The data obtained for the different measurements were statistically analysed using 
one-way and two-way analysis of variance (ANOVA) and general linear model to test the main effects and the interactions of the investigated factors (i.e., temperature and species). The significance between the different levels of the investigated factors was tested, and a multiple comparison using Tukey's test was carried out. Version 15 of Minitab (Brandon Court, Unit E1-E2, Progress Way, Coventry CV3 2TE, U.K.) was used for all analyses. For each temperature treatment, four replicates were used, and standard deviations and standard errors were determined using Microsoft Excel 2016.

\section{Results}

\section{Seed germination}

The effects of the three temperature treatments on the final germination percentages of the two Moringa species are illustrated in Fig. 1. At all the temperatures, seed germination started on the fourth day and was completed within the 14-day period of the germination trial. The effect of temperature on the germination performance was highly significant $(\mathrm{P}<0.001)$. At $15^{\circ} \mathrm{C}, M$. oleifera had a significantly higher percentage of germination compared to $M$. peregrina $(\mathrm{P}<0.05)$. Moreover, both species showed higher percentages of germination at $25^{\circ} \mathrm{C}$. The germination percentage approached $100 \%$ and $90 \%$ for $M$. oleifera and M. peregrina, respectively, while the lowest germination percentage $(60 \%)$ was achieved at $15^{\circ} \mathrm{C}$ for $M$. peregrina.

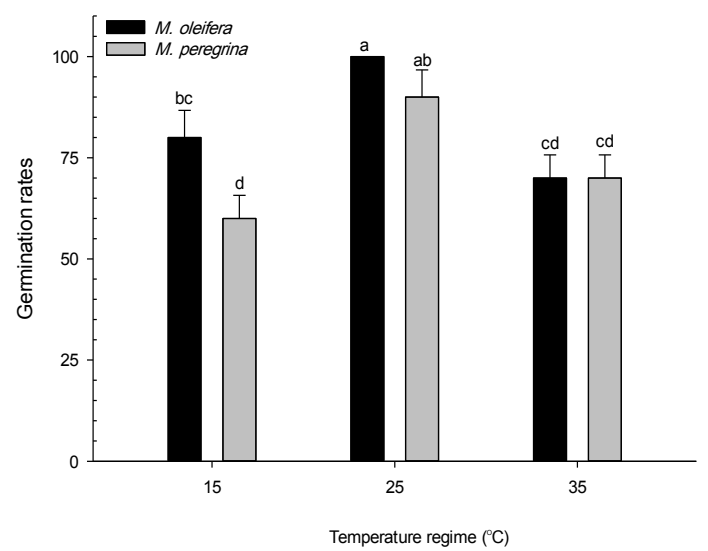

Fig. 1. The effect of temperature treatments $\left(15^{\circ} \mathrm{C}\right.$, $25^{\circ} \mathrm{C}$ and $35^{\circ} \mathrm{C}$ ) on seed germination (as $\%$ ) of the two Moringa species; M. oleifera and M. peregrina $[n=4$, mean \pm S.E., means that do not share the same letter are significantly different at $\mathbf{P} \leq \mathbf{0 . 0 5}$

Egypt. J. Bot. 61, No. 2 (2021)

\section{Plant growth parameters}

Several growth parameters were measured to determine how different temperature treatments influenced the growth parameters of the two Moringa species; the results are summarized in Table 1. Temperature significantly affected most growth parameters of the two Moringa species $(\mathrm{P}<0.001)$. The results showed that, most growth parameters of the two Moringa species grown at $25^{\circ} \mathrm{C}$ and $35^{\circ} \mathrm{C}$ were significantly increased when compared to their relative plants grown at $15^{\circ} \mathrm{C}(\mathrm{P}<0.01)$. The leaf number and leaf area of $M$. oleifera grown at $35^{\circ} \mathrm{C}$ were $631 \%$ and $547.5 \%$ higher, respectively, than those of the same species grown at $15^{\circ} \mathrm{C}$; these increases were the highest observed for these indices. Similarly, the plant height and root length of $M$. peregrina grown at $35^{\circ} \mathrm{C}$ approached $143.2 \%$ and $198.7 \%$ higher, respectively, than those of the same species grown at $15^{\circ} \mathrm{C}$, representing the maximum percentage increases for these indices. Moreover, the considerable percentage increases for most of the fresh and dry weights of both shoots and roots of $M$. oleifera were observed for plants grown at $35^{\circ} \mathrm{C}$ compared to those of the same species grown at $15^{\circ} \mathrm{C}(\mathrm{P}<0.001$; Table 1$)$.

\section{Photosynthesis measurements}

The results presented in Fig. 2 show the response of the uptake of photosynthetic $\mathrm{CO}_{2}(A)$ to photon flux (Q) for the two Moringa species grown in the three temperature treatments. The temperature treatments significantly affected the photosynthetic performance of the two Moringa species $(\mathrm{P}<0.001)$. Both Moringa species, the highest photosynthesis performance was observed at $25^{\circ} \mathrm{C}$ (Fig. 2). The rates of light saturation $\left(A_{\text {sat }}\right)$ for both Moringa species grown at $25^{\circ} \mathrm{C}$ were considerably higher than those of the same species grown at $35^{\circ} \mathrm{C}(\mathrm{P}<0.01$; Fig. 3A), with percentage increases for $M$. oleifera and $M$. peregrina of $63 \%$ and $29 \%$, respectively. Moreover, the quantum yield $(\varphi)$ of $M$. peregrina grown at $25^{\circ} \mathrm{C}$ was significantly greater than the quantum yield of the same species grown at $35^{\circ} \mathrm{C}$ $(\mathrm{P}<0.01$; Fig. 3B), with a $46 \%$ increase. However, both Moringa species showed significantly lower $A_{\text {sat }}$ and $\varphi$ at $15^{\circ} \mathrm{C}$ than at $25^{\circ} \mathrm{C}$ or $35^{\circ} \mathrm{C}$ $(\mathrm{P}<0.01$; Fig. 3A \& B). Measurements of the $A /$ $c_{i}$ curve for both Moringa species in the three temperature treatments are illustrated in Fig. 3. In general, the plateaus of the $A / c_{i}$ curve $\left(A_{\max }\right)$ and carboxylation efficiency for both Moringa species were considerably higher at $25^{\circ} \mathrm{C}$ than 
at $35^{\circ} \mathrm{C}(\mathrm{P}<0.01$; Fig. $3 \mathrm{C} \& \mathrm{D})$. For $M$. oleifera, the highest percentage increases in $A_{\max }$ and carboxylation efficiency were observed for plants grown at $25^{\circ} \mathrm{C}$; these were $87 \%$ and $168 \%$ higher, respectively, than those of the same species grown at $35^{\circ} \mathrm{C}(\mathrm{P}<0.01$; Fig. 3$)$. On the other hand, both Moringa species showed significantly lower $A_{\max }$ and carboxylation efficiency values when grown at $15^{\circ} \mathrm{C}$ than at 25 or $35^{\circ} \mathrm{C}(\mathrm{P}<0.01$; Fig. 3C \& D).

TABLE 1. Effects of temperature on the growth parameters of M. oleifera and M. peregrina

\begin{tabular}{lcccc}
\hline Trait & Species & $\mathbf{1 5}^{\mathbf{}} \mathbf{C}$ & $\mathbf{2 5}^{\circ} \mathbf{C}$ & $\mathbf{3 5}^{\circ} \mathbf{C}$ \\
\hline \multirow{2}{*}{ Plant height $(\mathrm{cm})$} & M. oleifera & $18^{\mathrm{bc}} \pm 1.25$ & $24.4^{\mathrm{b}} \pm 2.3$ & $43^{\mathrm{a}} \pm 4.16$ \\
& M. peregrina & $8.4^{\mathrm{d}} \pm 0.56$ & $16.67^{\mathrm{c}} \pm 1.85$ & $20.43^{\mathrm{bc}} \pm 1.45$ \\
Leaf number & M. oleifera & $40^{\mathrm{d}} \pm 0.58$ & $223.3^{\mathrm{b}} \pm 9.21$ & $292.4^{\mathrm{a}} \pm 13.62$ \\
& M. peregrina & $15^{\mathrm{e}} \pm 1.73$ & $41^{\mathrm{d}} \pm 7.57$ & $72.3^{\mathrm{c}} \pm 6.84$ \\
Leaf area $\left(\mathrm{cm}^{2}\right)$ & M. oleifera & $80^{\mathrm{cd}} \pm 1.15$ & $446.7^{\mathrm{b}} \pm 18.41$ & $518^{\mathrm{a}} \pm 43.55$ \\
& M. peregrina & $22.5^{\mathrm{d}} \pm 2.59$ & $62^{\mathrm{cd}} \pm 11.75$ & $108.5^{\mathrm{c}} \pm 10.26$ \\
Shoot fresh weight $(\mathrm{g})$ & M. oleifera & $2.16^{\mathrm{c}} \pm 0.37$ & $10.23^{\mathrm{b}} \pm 1.57$ & $20.1^{\mathrm{a}} \pm 1.07$ \\
& M. peregrina & $2.8^{\mathrm{c}} \pm 1.55$ & $4.1^{\mathrm{c}} \pm 0.28$ & $5.1^{\mathrm{c}} \pm 1.29$ \\
Shoot dry weight $(\mathrm{g})$ & M. oleifera & $0.5^{\mathrm{cd}} \pm 0.11$ & $1.4^{\mathrm{b}} \pm 0.2$ & $3.43^{\mathrm{a}} \pm 0.24$ \\
& M. peregrina & $0.23^{\mathrm{d}} \pm 0.03$ & $0.38^{\mathrm{cd}} \pm 0.05$ & $0.84^{\mathrm{c}} \pm 0.21$ \\
Root length $(\mathrm{cm})$ & M. oleifera & $6.5^{\mathrm{bc}} \pm 1.25$ & $11.83^{\mathrm{ab}} \pm 1.48$ & $12.16^{\mathrm{a}} \pm 1.58$ \\
& M. peregrina & $5.3^{\mathrm{c}} \pm 0.34$ & $8.5 \mathrm{~b}^{\mathrm{c}} \pm 1.04$ & $15.83^{\mathrm{a}} \pm 3.65$ \\
Root fresh weight $(\mathrm{g})$ & M. oleifera & $0.56^{\mathrm{e}} \pm 0.18$ & $7.33^{\mathrm{c}} \pm 0.55$ & $11.1^{\mathrm{a}} \pm 0.44$ \\
& M. peregrina & $0.4^{\mathrm{e}} \pm 0.11$ & $3.93^{\mathrm{d}} \pm 0.46$ & $9.76^{\mathrm{b}} \pm 0.52$ \\
Root dry weight $(\mathrm{g})$ & M. oleifera & $0.06^{\mathrm{e}} \pm 0.02$ & $0.8^{\mathrm{c}} \pm 0.17$ & $1.56^{\mathrm{a}} \pm 0.03$ \\
& M. peregrina & $0.12^{\mathrm{e}} \pm 0.09$ & $0.4^{\mathrm{d}} \pm 0.05$ & $1.17^{\mathrm{b}} \pm 0.03$ \\
\hline
\end{tabular}

- $\mathrm{n}=4$, mean \pm S.E

- Means that do not share a letter are significantly different at $\mathrm{P} \leq 0.05$
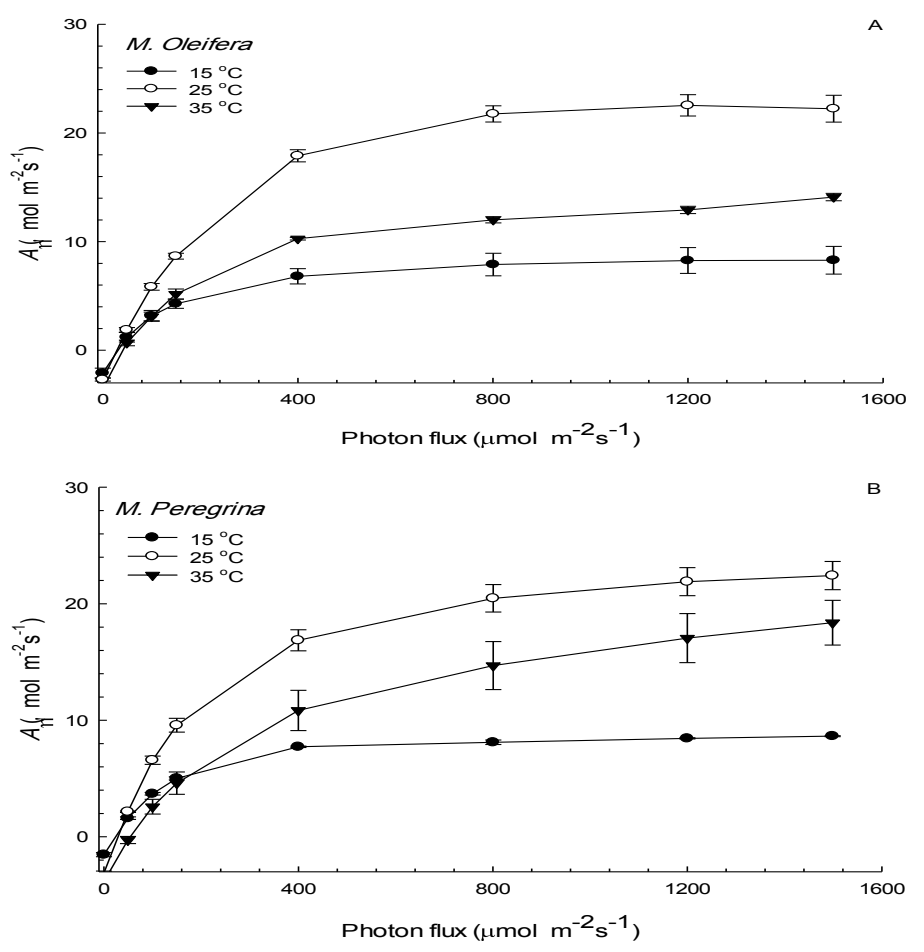

Fig. 2. The photosynthetic $\mathrm{CO}_{2}$ absorption response (A) per unit area of the leaf to photon flux (Q) for two Moringa species; $M$. oleifera and $M$. peregrina $\left[\mathrm{n}=4\right.$, mean \pm S.E., $\mathrm{CO}_{2}$ absorption measurements were all made at $25^{\circ} \mathrm{C}$ and $\mathrm{C}_{\mathrm{a}}$ of $410 \mu \mathrm{mol} \mathrm{mol}{ }^{-1}$ ] 

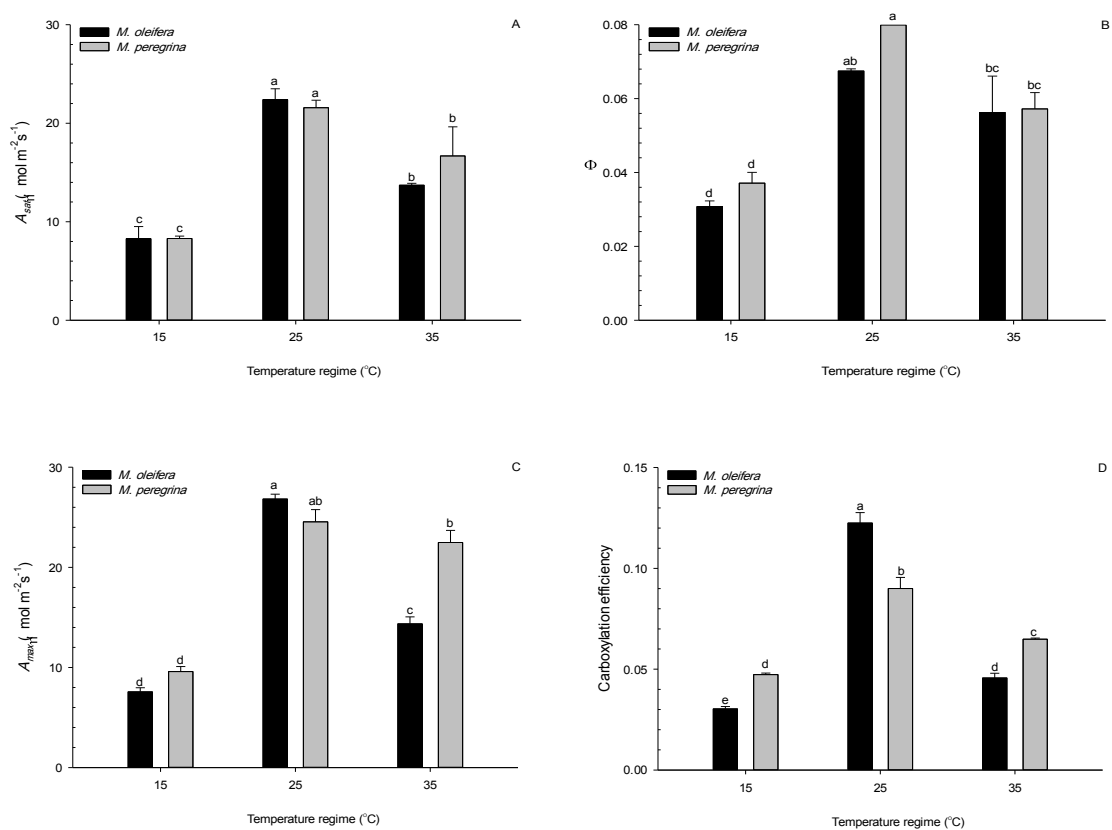

Fig. 3. The effect of temperature treatments $\left(15^{\circ} \mathrm{C}, 25^{\circ} \mathrm{C}\right.$ and $\left.35^{\circ} \mathrm{C}\right)$ on physiological parameters of the two Moringa species; M. oleifera and M. peregrina $[\mathrm{n}=4$, mean \pm S.E., (A)Asat, (B) Quantum yield, (C) Amax and (D) Carboxylation efficiency. Means that do not share the same letter are significantly different at $P \leq 0.05]$

\section{Chlorophyll content determination}

Figure 4B illustrated the effect of the three temperature treatments on the chlorophyll content of M. oleifera and M. peregrina. The chlorophyll contents of $M$. peregrina were significantly increased by increasing the temperature from $15^{\circ} \mathrm{C}$ to $35^{\circ} \mathrm{C} \quad(\mathrm{P}<0.01)$. The chlorophyll contents of $M$. peregrina grown at $25^{\circ} \mathrm{C}$ and $35^{\circ} \mathrm{C}$ increased by $29 \%$ and $117 \%$, respectively, compared to those of the same species grown at $15^{\circ} \mathrm{C}(\mathrm{P}<0.01)$. However, the three temperature treatments did not induce significant variation in the chlorophyll content of M. oleifera.
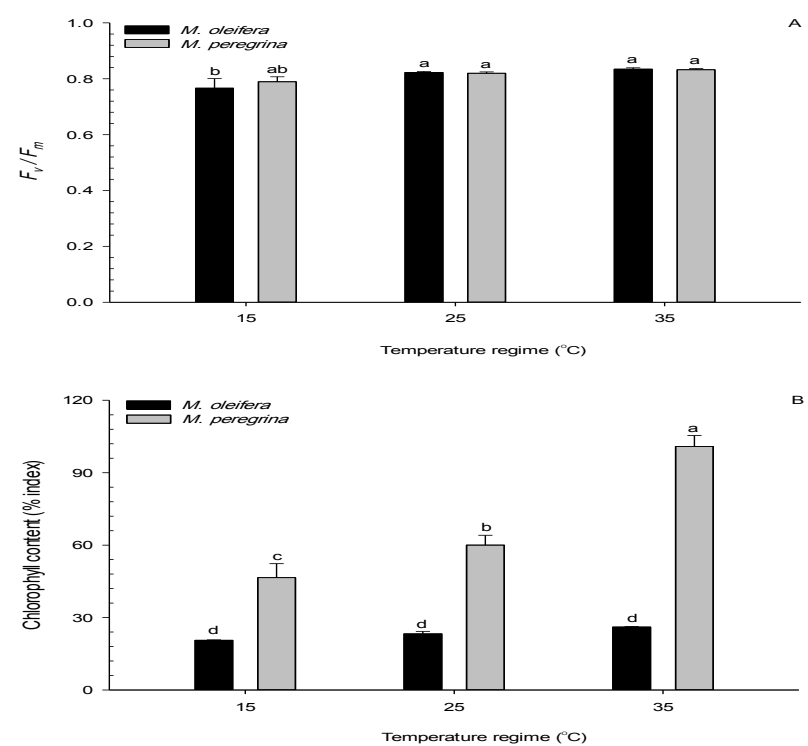

Fig. 4. The effect of temperature treatments $\left(15^{\circ} \mathrm{C}, 25^{\circ} \mathrm{C}\right.$ and $\left.35^{\circ} \mathrm{C}\right)$ on physiological parameters of the two Moringa species; M. oleifera and M. peregrina $\left[\mathrm{n}=4\right.$, mean \pm S.E., (A) $F_{v} / F_{m}$ and (B) Chlorophyll content. Means that do not share the same letter are significantly different at $P \leq 0.05$ ]

Egypt. J. Bot. 61, No. 2 (2021) 


\section{Chlorophyll fluorescence measurements}

The maximum quantum efficiency of the photochemistry of PSII $(F v / F m)$ of the two Moringa species grown in the three temperature treatments is shown in Fig. 4A. For both Moringa species, the $F v / F m$ values of the plants grown at $35^{\circ} \mathrm{C}$ were similar to those plants grown at $25^{\circ} \mathrm{C}$. However, the chlorophyll fluorescence parameter of $M$. oleifera plants grown at $15^{\circ} \mathrm{C}$ was significantly decreased compared to their analogues parameters of the two Moringa species grown at $25^{\circ} \mathrm{C}$ and $35^{\circ} \mathrm{C}(\mathrm{P}<0.05)$.

\section{Discussion}

The present study examined the responses of seed germination, seedling growth and photosynthesis of two Moringa species to temperature. Temperature is one of the most significant factors influencing seed germination and seedling development (Zhao et al., 2014; Wang et al., 2020). The results showed that seeds of both Moringa species germinated over a wide range of temperatures, from $15^{\circ} \mathrm{C}$ to $35^{\circ} \mathrm{C}$ (Fig. 1). The germination of the two Moringa species in all the temperature treatments began on day 4 of the experimental period. The germination suppression reported in the first days of this study is consistent with some previous studies which showed germination delays for few days (Redondo et al., 2004; Yan et al., 2011A; Causin et al., 2020). This indicated the need for optimal environmental conditions to ensure a high percentage of germination and thus growth efficiency (Redondo et al., 2004). Furthermore, the results obtained showed that the optimum temperature for seed germination of both Moring a species was $25^{\circ} \mathrm{C}$. Similar findings have been reported for M. oleifera (Muhl et al., 2011A; Zhang et al., 2017).

Temperature is one of the main influential and uncontrollable climate factors that regulate plant development and growth (Munir, 2004). For both Moringa species used in this study, all the growth parameters were higher at $35^{\circ} \mathrm{C}$ than $15^{\circ} \mathrm{C}$ (Table 1). The optimum temperature for seedling growth of both Moringa species was $35^{\circ} \mathrm{C}$. It was previously reported that the optimum temperatures for seedling growth in Moringa ranged from $20^{\circ} \mathrm{C}$ to $35^{\circ} \mathrm{C}$ (Alatar, 2011; Muhl et al., 2011A). M. oleifera grown at $35^{\circ} \mathrm{C}$ showed better growth performance, especially leaf number and leaf area, than M. peregrina.
The considerably greater leaf area of $M$. oleifera increased the total number of stomata per plant, resulting in increased growth of vegetation and accumulation of dry matter (Muhl et al., 2011B). Furthermore, the highest percentage increase was observed for the fresh and dry weights of the shoots and roots of $M$. oleifera grown at $35^{\circ} \mathrm{C}$ compared with those of the same species grown at $15^{\circ} \mathrm{C}$ (Table 1). Genetic variations between the two studied species and their distinct origins can explain the differences observed (Mridha, 2015; Muhammad et al., 2016). Furthermore, the ability of the two Moringa species to develop over a large range of temperatures, from $15^{\circ} \mathrm{C}$ to $35^{\circ} \mathrm{C}$, may support their distribution and use as important crops for medicine and nutrition (Hassanein \& Al-Soqeer, 2017).

Temperature also significantly affected the gas exchange parameters of both Moringa species in this study. The photosynthetic measurements showed that the optimum temperature for gas exchange of both Moringa species was $25^{\circ} \mathrm{C}$ (Fig. 3). Additionally, both Moringa species showed nearly similar photosynthetic performances at $25^{\circ} \mathrm{C}$ and $35^{\circ} \mathrm{C}$. However, a temperature of $15^{\circ} \mathrm{C}$ caused a substantial decrease in the $A_{\text {sat }}, \varphi, A_{\max }$ and carboxylation efficiencies of both Moringa species compared with those of plants grown in the other temperature treatments. The inhibition of photosynthesis in Moringa plants grown at $15^{\circ} \mathrm{C}$ may be due in part to a reduction in stomatal conductance or a decrease in photosynthetic pigments. All these factors affect photosystem II (PSII) activities, clearly contributing to the deactivation of enzymes that play a key role in the photosynthetic process (Ashraf \& Harris, 2013; Li et al., 2015). A decrease in the photosynthetic performance of Moringa was previously observed at low temperatures in controlled environments and fields (Mabapa et al., 2018). There are many physiological mechanisms that allow these two Moringa species to cope effectively with harsh environmental conditions, such as temperature stress (Mabapa et al., 2018). Furthermore, Chaves (1991) found that the primary processes adversely affected by drought and higher temperatures are gas exchange operations, primarily those related to photosynthetic rates. The results of this study showed that the photosynthetic parameters of the two Moringa species were significantly lower at $35^{\circ} \mathrm{C}$ than at $25^{\circ} \mathrm{C}$. Similar findings were reported by Mabapa et al. (2018), who found that higher temperatures in summer months had 
a negative impact on the photosynthetic rate of M. oleifera. This reduction in the photosynthetic process of the two Moringa species could be the result of stomatal limitations and reductions in the chlorophyll and carotenoid contents (Sharma et al., 2019; Morales et al., 2020). Other reasons for the reduction in the photosynthetic process could be limitations in the electron transport of the thylakoid membrane or decreases in the activity of Rubisco (Sharma et al., 2019; Morales et al., 2020).

The findings of this research showed that the chlorophyll content in the leaves of $M$. peregrina increased as the temperature increased (Fig. 4B). The highest increase in chlorophyll content was recorded for $M$. peregrina grown at $35^{\circ} \mathrm{C}$. The leaves of plants grown in the highest temperature treatment area visible sign of this increase. The reason for this increase could be the rise in the number of chloroplasts within leaves developed at high temperatures. However, the chlorophyll contents in the leaves of $M$. oleifera were similar across the three temperature treatments. The chlorophyll contents of $M$. peregrina leaves were significantly higher than the chlorophyll contents of $M$. oleifera leaves in all the temperature treatments. Similar findings were reported by Hassanein \& Al-Soqeer (2017), who found that $M$. peregrina accumulated greater chlorophyll contents than $M$. oleifera when grown under field conditions.

Chlorophyll fluorescence measurement has been used to determine the integrity of photosystem II when exposed to stress (Shabala \& Shabala, 2002). In this study, chlorophyll fluorescence $(F v / F m)$ was not affected by the temperature treatments in either Moringa species, except the $15^{\circ} \mathrm{C}$ treatment, in which a slight decrease was recoded for $M$. oleifera (Fig. 4A). These high $F v / F m$ values offered clear evidence that both Moringa species were resistant to photo inhibition when grown under different temperature treatments. Similar results have been reported previously for Pennisetum purpureum grown in two temperature treatments (AL-Shoaibi, 2008). Thus, the current research shows that chlorophyll fluorescence cannot be considered one of the variables for regulating the rate of net $\mathrm{CO}_{2}$ assimilation in Moringa species grown at different temperatures. On the other hand, the slight decrease in the $F v / F m$ values of $M$. oleifera grown at $15^{\circ} \mathrm{C}$ could result from oxidative damage to photosynthetic organelles, particularly under temperature stress (Aro et al., 1993; Yan et al., 2011B).

\section{Conclusion}

The present study showed that both $M$. peregrina and $M$. oleifera have similar responses to different temperature treatments. The optimum temperature for both species, leading to the highest percentage of germination and best photosynthetic performance, is $25^{\circ} \mathrm{C}$. The results also showed that $35^{\circ} \mathrm{C}$ was the optimal temperature for most parameters of growth of the two Moringa species. However, the chlorophyll contents of $M$. oleifera and most values of $F v /$ $\mathrm{Fm}$ for both species were similar across the three temperature treatments. Additionally, the outcomes of this study showed that Moringa can be cultivated in many different regions with different temperatures.

Ethical approval: Not applicable.

Research funding: The author state no funding involved

Data availability: Data that are supplementary to the manuscript will be available by request.

\section{$\underline{\text { References }}$}

Abd El-Hack, M.E., Alagawany, M., Elrys, A.S., Desok, E.M., Tolba, H.M.N., et al. (2018) Effect of forage Moringa oleifera L. (moring) on animal health and nutrition and its beneficial application in soil, plants and water purification. Agriculture, 8(9), 145.

Alatar, A.A. (2011) Effect of temperature and salinity on germination of Achillea fragrantissima and Moring peregrina from Saudi Arabia. African Journal of Biotechnology, 10, 3393-3398.

AL-Shoaibi, A.A. (2008) Photosynthetic response to the low temperature in Elephant grass (Pennisetum purpureum) and Zea Mays. International Journal of Botany, 4(3), 309-314.

Amaglo, N.K., Bennett, R.N., Lo Curto, R.B., Rosa, E.A.S., et al. (2010) Profiling selected phytochemicals and nutrients in different tissues of the multipurpose tree Moringa oleifera L., grown in Ghana. Food Chemistry, 122, 1047-1054. 
Anjula, P., Pradheep, K., Rita, G., Eroshini, N., Bhandari, D.C. (2011) Drumstick tree (Moringa oleifera Lam.): a multipurpose potential species in India. Genetic Resources and Crop Evolution, 58, 453-460.

Aro, E.M., Virgin, I., Andersson, B. (1993) Photoinhibition of Photosystem II. Inactivation, protein damage and turnover. Biochimica et Biophysica Acta, 5(2), 113-134.

Ashraf, M., Harris, P.J.C. (2013) Photosynthesis under stressful environments: An overview. Photosynthetica, 51, 163-190.

Ayerza, R. (2019) Seed characteristics, oil content and fatty acid composition of moringa (Moringa oleifera Lam.) seeds from three arid land locations in Ecuador. Industrial Crops and Products, 140, 111575 .

Boukandoul, S., Casal, S., Zaidi, F. (2018) The potential of some Moringa species for seed oil production. Agriculture, 8(10), 150.

Boulos, L. (1999) "Flora of Egypt". vol. I (AzollaceaeOxalidaceae). Al Hadara Publishing Cairo, Egypt.

Causin, H.F., Bordón, D.A.E., Burrieza, H. (2020) Salinity tolerance mechanisms during germination and early seedling growth in Chenopodium quinoa Wild. genotypes with different sensitivity to saline stress. Journal of Experimental Botany, 172, 103995.

Chaves, M.M. (1991) Effects of water deficits on carbon assimilation. Journal of Experimental Botany, 42, 1-16.

Collatz, G.J., Ribas-Carbo, M., Berry, J.A. (1992) Coupled photosynthesis-stomatal model for leaves of $\mathrm{C}_{4}$ plants. Australian Journal of Plant Physiology, 19, 519-538.

Da Silva, J.P., Serra, T.M., Gossmann, M., Wolf, C.R., Meneghetti, M.R., Meneghetti, S.M. (2010) Moringa oleifera oil: studies of characterization and biodiesel production. Biomass and Bioenergy, 34, 1527-1530.

El-Lamey, T.M. (2015) Ecophysiological responses of Moringa peregrina (Forssk) Fiori growing naturally under different habitat conditions of Eastern Desert and Fieran Oasis, Egypt. IOSR
Journal of Agriculture and Veterinary Science, 8(4), 8-21.

Hassanein, A.M.A., Al-Soqeer, A.A. (2017) Evaluation of seed germination and growth characteristics of Moringa oleifera and Moringa peregrina under laboratory, greenhouse and field conditions. International Journal of Agriculture and Biology, 19, 873-879.

Hegazy, A.K., Hammouda, O., Lovett-Doust, J., Gomaa, N.H. (2008) Population dynamics of Moringa peregrina along altitudinal gradient in the northwestern sector of the Red Sea. Journal of Arid Environments, 72, 1537-1551.

Khor, K.Z., Vuanghao, L., Moses, E.J., Samad, N.A. (2018) The in vitro and in vivo anti-cancer properties of Moringa oleifera. Evidence-Based Complementary and Alternative Medicine, 2018(2), 1-14. DOI:10.1155/2018/1071243

Leone, A., Spada, A., Battezzati, A., Schiraldi, A., Aristil, J., Bertoli, S. (2015) Cultivation, genetic, ethnopharmacology, photochemistry and pharmacology of Moringa oleifera leaves: An overview. International Journal of Molecular Science, 16, 12791-12835.

Li, Z., Wu, N., Liu, T., Chen, H., Tang, M. (2015) Effect of arbuscular mycorrhizal inoculation on water status and photosynthesis of Populus cathayana males and females under water stress. Physiologia Plantarum, 155, 192-204.

Mabapa, M.P., Ayisi, K.K., Mariga, I.K. (2018) Seasonal effect on Moringa oleifera gaseous exchange and water use efficiency under diverse planting densities. Journal of Applied Botany and Food Quality, 91, 219-225.

Maxwell, K., Johnson, G.N. (2000) Chlorophyll fluorescence - a practical guide. Journal of Experimental Botany, 51, 659-668.

Melesse,A., Steingass, ssH., Boguhn, J., Schollenberger, M., Rodehutscord, M. (2012) Effects of elevation and season on nutrient composition of leaves and green pods of Moringa stenopetala and Moringa oleifera. Agroforestry Systems, 86, 505-518.

Morales, F., Ancín, M., Fakhet, D., González-Torralba, J., Gámez, A.L., et al. (2020) Photosynthetic metabolism under stressful growth conditions as a 
bases for crop breeding and yield improvement: A review. Plants, 9 (1), 88.

Mridha, M.A.U. (2015) Prospects of Moringa Cultivation in Saudi Arabia. Journal of Applied Environmental and Biological Sciences, 5 (3), 3946.

Muhammad, H.I., Asmawi, M.Z., Khan, N.A.K. (2016) A review on promising phytochemical, nutritional and glycemic control studies on Moringa oleifera Lam. in tropical and sub-tropical regions. Asian Pacific Journal of Tropical Biomedicine, 6, 896902.

Muhl, Q.E. (2009) Seed germination, tree growth and flowering responses of Moringa oleifera Lam. (Horseradish tree) to temperature. MSc Thesis, Pretoria: University of Pretoria, Republic of South Africa.

Muhl, Q.E., Toit, E.S., Robbertse, P.J. (2011 A) Moringa oleifera (Horseradish tree) leaf adaptation to temperature regimes. International Journal of Agriculture and Biology, 13, 1021-1024.

Muhl, Q.E., Toit, E.S., Robbertse, P.J. (2011 B) Temperature effect on seed germination and seedling growth of Moringa oleifera Lam. Seed Science and Technology, 39, 208-213.

Munir, M., Jamil, M., Baloch, J., Khattak, K.R. (2004) Growth and flowering of Antirrhinum majus L. under varying temperatures. International Journal of Agriculture and Biology, 6, 173-178.

Olson, M.E., Carlquist, S. (2001) Stem and root anatomical correlations with life form diversity, ecology, and systematics in Moringa (Moringaceae). Botanical Journal of the Linnean Society, 135, 315-348.

Pandey, A., Pradheep, K., Gupta, R., Nayar, E.R., Bhandari, D.C. (2011) 'Drumstick tree' (Moringa oleifera Lam.): A multipurpose potential species in India. Genetic Resources and Crop Evolution, 58, 453-460.

Pandey, S.K., Singh, H. (2011) A Simple, CostEffective Method for Leaf Area Estimation. Journal of Botany, Article ID 658240. https://doi. org/10.1155/2011/658240.

Posch, B.C., Kariyawasam, B.C., Bramley, H.,
Coast, O., Richards, R.A., Reynolds, M.P., et al. (2019) Exploring high temperature responses of photosynthesis and respiration to improve heat tolerance in wheat. Journal of Experimental Botany, 70, 5051-5069.

Ramachandran, C., Peter, K.V., Gopalakrishnan, P.K. (1980) Drumstick (Moringa oleifera) multipurpose Indian vegetable. Economic Botany, 34, 276-283.

Redondo, S., Rubio-Casal, A.E., Castillo, J.M., Luque, C.J., Álvarez, A.A., et al. (2004) Influences of salinity and light on germination of three Sarcocornia taxa with contrasted habitats. Aquatic Botany, 78(3), 255-264.

Savitch, L.V., Massacci, A., Gray, G.R., Huner, N.P.A. (2000) Acclimation to low temperature or high light mitigates sensitivity to photoinhibition: roles of the Calvin cycle and the Mehler reaction. Australian Journal of Plant Physiology, 27, 253-264.

Shabala, S., Shabala, L. (2002) Kinetics of net H+, $\mathrm{Ca}^{2+}, \mathrm{K}^{+}, \mathrm{Na}^{+}, \mathrm{NH}_{4}^{+}$, and $\mathrm{Cl}^{-}$fluxes associated with post-chilling recovery of plasma membrane transporters in Zea mays leaf and root tissues. Physiologia Plantarum, 114, 47-56.

Sharma, A., Kumar, V., Shahzad, B., Ramakrishnan, M., Sidhu, G.P.S., et al. (2019) Photosynthetic response of plants under different abiotic stresses: A review. Journal of Plant Growth Regulation, 39, 509-531.

Tesfay, S., Bertling, I., Odindo, A., Workneh, T., Mathaba, N. (2011) Levels of antioxidants in different parts of moringa (Moringa oleifera) seedling. African Journal of Agricultural Research, 6, 5123-5132.

Tesfay, S.Z., Modi, A.T., Mohammed, F. (2016) The effect of temperature in moringa seed phytochemical compounds and carbohydrate mobilization. South African Journal of Botany, 102, 190-196.

Urban, J., Ingwers, M.W., McGuire, M.A., Teskey, R.O. (2017) Increase in leaf temperature opens stomata and decouples net photosynthesis from stomatal conductance in Pinus taeda and Populus deltoides x nigra. Journal of Experimental Botany, 68(7), 1757-1767.

Von Caemmerer, S., Farquhar, G.D. (1981) Some 
relationships between the biochemistry of photosynthesis and gas exchange of leaves. Planta, 53, 376-387.

Wang, Q., Qu, B., Mi, J., Ma, L., Xu, Y., Shao, M. (2020) The effect of temperature on seed germination and seedling growth of two invasive plants in Roroppa. Biotechnology Journal International, 24(5), 39-48.

Wasonowati, C., Sulistyaningsih, E., Indradewa, D., Kurniasih, B. (2019) Physiological characters of Moring oleifera Lamk in Madura. International Conference on Biology and Applied Science, 2120(1), 030024. https://doi. org/10.1063/1.5115628.

Yan, C., Wei, Y., Yang, M. (2011 A) Comparative germination of Tamarix ramosissima spring and summer seeds. Experimental and Clinical Sciences Journal, 10, 198-204.

Yan, K., Chen, P., Shao, H., Zhang, L., Xu, G. (2011 B) Effects of short-term high temperature on photosynthesis and photosystem II performance in sorghum. Journal of Agronomy and Crop Science, 197, 400-408.
Youssef, T. (2007) Stomatal, biochemical and morphological factors limiting photosynthetic gas exchange in the mangrove associate Hibiscus tiliaceus under saline and arid environment. Aquatic Botany, 87, 292-298.

Zhang, T.X., Lin, Y.H., Lin, Z.K., Chen, Z.D., Yang, J.J., Cao, M.H. (2017) Effects of different temperature treatments on seed germination, seedling growth and physiological characteristics of M. oleifera Lam. Chinese Journal of Tropical Crops, 38, 438-443.

Zhao, T.T., Li, Y.X., He, J.D. (2014) Effect of temperature stress on seed germination of Chimonanthus praecox (J). Journal of Mianyang Normal University, 33, 63-68.

Zheng, Y., Sun, H., Zhang, Y., Wu, J. (2019) Evaluation of the adaptability, productivity, and leaf powder quality of eight Moringa oleifera cultivars introduced to a dry-hot climate of Southwest China Industrial Crops and Products, 128, 199-205.

\section{إنبات البذور ونمو الثتلات واستجابات البناء الضوئي لارجة الحرارة في الثجرة

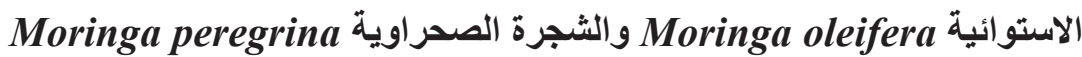

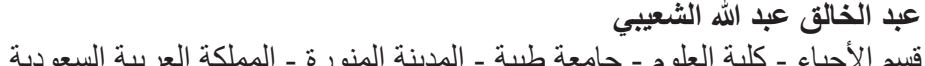

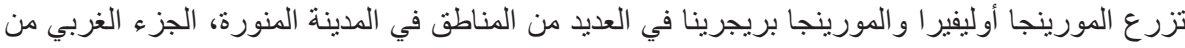

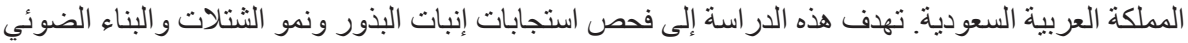

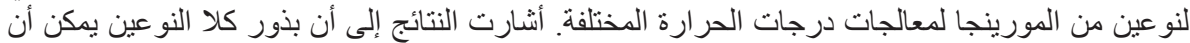

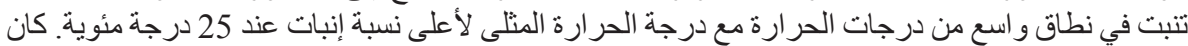

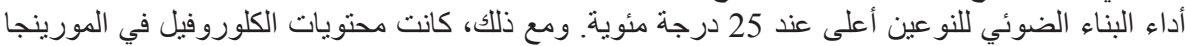

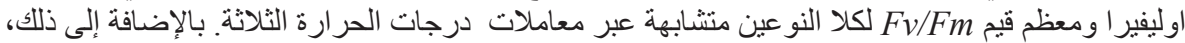

أظهرت نتائج هذه الدر اسة أنه يمكن زر اعة المورينجا في مناطق عديدة بدرجات دات درات حرارة مختلفة.
} 